\title{
A Study of Autobiographies: Confessions, Facts, Fiction and Hypothesis
}

\author{
Mohammed Osman Abdul Wahab \\ Department of English, Faculty of Languages and Translation, King Khalid University Abha, Kingdom of Saudi Arabia \\ Nisar Ahmad Koka \\ Department of English, Faculty of Languages and Translation, King Khalid University Abha, Kingdom of Saudi Arabia \\ Mohammed Nurul Islam \\ Department of English, Faculty of Languages and Translation, King Khalid University Abha, Kingdom of Saudi Arabia
}

\begin{abstract}
Since ancient times, man has attempted to express his inner feelings, covetousness and inclination to the world through various mediums e.g. poetry, drama, story, etc. Literature is one of the outcomes of the man's efforts to reveal his aspirations to the world. Literature has avalanche of the widespread genre which is always subject to precisely apprehend and assimilate. Biography and autobiography are the two different genres of literature. The life of an individual is full of sweet and bitter experiences. There are incidences in an individual's life which he or she never wants to share with anybody. Politicians, Rulers, Socialites, Movie Stars and other public personalities are also normal human beings. They too have their personal share of problems in their lives and in an attempt to resolve those issues they sometimes commit mistakes and even crimes which they never want anyone to know. Sometimes they commit these mistakes, misdemeanours, felonies or crimes because of their lustful desires or inclinations. The present paper is a result of interest and curiosity to know if individuals share such information in their autobiographies.
\end{abstract}

Index Terms - autobiographies, truth in autobiographies, Urdu autobiographies, confessions, facts in autobiographies, fiction in autobiographies, the element of exaggeration in autobiographies

\section{WHAT IS AN AUTOBIOGRAPHY}

Autobiography is an account of events and different episodes of a person's life. However, it is an aesthetic depiction of one's life. The Oxford Reference Dictionary defines that autobiography is "[A] personal account of one's own life especially for publication". Thus, it suggests that an autobiography is biography of a person's life as Abrams in his book A Handbook of Literary Terms rightly defines that an "[A]utobiography is a biography written by the subject about himself or herself" (Abrams, p. 31). Autobiographies give an insight in the subconscious mind of the writer. We can guess the flow of ideas in the mind of the writer by reading his autobiography or the autobiographical work. This type of knowledge is not only interesting but also intriguing as well as sometimes inspiring and instructive.

When you read a novel you, sometimes, sympathise with the protagonist. You feel pity for the sufferings of the central character. You start hating the wicked or villainous characters. Even in the autobiographies you start sympathizing with the author and start hating the people who, according to the author, are the perpetrators of crime or who persecute the author. Prasad rightly asserts that "no one can know so well as the writer of the autobiography himself what motives prompted him at decisive moments, what his secret hopes and ambitions were, and how far his career fulfilled his real aspirations"

\section{HISTORY}

The advent of the first autobiography, in various languages and different parts of the world, is a matter of discussion. The Renaissance witnesses the first European autobiography by Margery Kempe, an Italian mystic dictated an account of her life during this period. Baxter's and John Bunyan's Autobiographies, in 17th century England, are the examples of religious life-accounts. Apology for the life of Colley Cibber, Comedian by Colley Cibber, in the 18th century, attracted the readers. Autobiographies, written by the distinguished writers like Benjamin Franklin, Edward Gibbon and Rousseau, marked a great history. Moreover, Wordsworth's Prelude' and Byron's Childe Harold are the inspiration from Rousseau's 'Confessions'.

The first autobiography written in Indian English was Raja Rammohan Roy's short autobiographical sketch (1833) which is a very realistic presentation. Lutufullah, a tutor in Persian, Arabic and Hindustani to British officers wrote the first extensive autobiography in 1857. Some of the epoch-making autobiographies were written by prominent freedom fighters and great Indian leaders. Surendranath Banerjee's A Nation Making (1925) is a live commentary about the political turmoil of those days and how India moved towards indipendence, Mahtma Gadhi's The Story of My Experiments with Truth (1927) which was translated into English in 1940 by Mahadevbhai Desai. The two vitally 
important autobiographies are Lala Lajpat Rai's The Story of My Deportation (1908) and Jawaharlal Nehru's An Autobiography (1936). Nehru's autobiography, an epitome of introspection, is a living record of the Indian history.

\section{AN Autobiography, AUtOBIOGRAPHICAL WORK OR A DiARY}

There is a huge difference between an autobiography and a diary. Autobiographical works are sometimes poles apart than the diary and autobiography. In an autobiographical work the author uses the fictional names and characters to speak his own story. Sometimes the author even crosses the thin line between the facts and fiction. That is the reason autobiographical works can never be considered as an authentic record of once life. Babur, the founder of Mughal Empire in India, wrote his memoirs Tuzak-e-Babri and his grandson wrote his famous memoirs named s Tuzak-eJahangiri but they are not considered as autobiographies.

\section{AutobIOGRAPHY AND LETTERS}

We can define autobiography as a record of the history of once life. An autobiography is record of the events of once life and incidences through his own prism. Letters are a sort of communication between two or more individuals. There are people who keep exact record of event by noting them down in journals and when they write autobiography they can quote the incidences exactly as they happen. On the contrary there are people who do not have any written records and they quote incidences from their memory. Now the biggest question is how far a man can trust his memory. Human memory degenerates with the passage of time and it is not trustworthy for the event which takes place in the distant past. There are many incidences when the authors could not recall the events of the past exactly as they had happened and quoted them inaccurately. One of the greatest journalists and writers of India, Khushwant Singh who wrote his autobiography by the name 'Truth, love \& a little malice' quoted the incidences of the life of the then prime minister of India Mrs Indira Gandhi. The daughter in law of the Prime Minister, Meneka Gandhi, who was mentioned in a bad light said in an interview to an Indian national daily in so many words that Khuswant Singh is an old man and his memory is no more trustworthy. There are several autobiographies which landed the author in trouble. Some people even go to the court of law and put stay on the publication of the work. However, autobiography "is not the annals of a man's life, but its 'philosophical history' sometimes the writer hides some important events of life because those events may put writer in a bad light in front of the reader or general public. But on the contrary some writers have used their autobiographies as a weapon for maligning the character of others. This can also be called as character assassination of others. Reham Khan the former wife of the Prime Minister of Pakistan Imran Khan, even goes to the extent of saying that Imran Khan used to take drugs in the bathroom. While talking about her first husband she mentions him as if he was not a man but a monster who never paid any attention to her or her children's feelings. On the other hand she depicts herself as the one who wanted to continue the relations but both the men i.e her first husband and her second husband were responsible for the break up. Ironically Reham Khan's autobiography released when her former husband was contesting the general elections in Pakistan. Although her autobiography did not have a very damaging effect on the political career of her former husband but the autobiography was widely read and discussed during the elections. You will hardly come across any autobiography where the writer candidly confesses about his or her mistakes and takes the responsibility of the mistakes and crimes committed.

Zahiruddin Babur (1483 - 1530 ) the founder of the great Mughal Empire in India, in his Baburnama, also known as Tuzke Babri, writes about his interests in homosexuality and how he was 'maddened and afflicted' towards a boy in Urdu Bazar. Qudratullah Shahab (1920-1986) a renowned Urdu writer and diplomat in his autobiography 'Shahabnama' writes about his childhood infatuation towards the beautiful young wife of his teacher. When the region of Jammu was hit by the worst kind of plague and his teacher, the husband of the beautiful young lady, caught with the plague, Qudratullah, enamoured with his infatuation, wished death for him. Unfortunately for him, his teacher survived but after a few days his beautiful wife got infected with plague and died. He also mentioned how he used to steal money, thrown in charity, from the grave of a famous Sufi Saint. The first chapter of his autobiography 'Shahabnama' is 'Iqbal e Jurm' confession. Mahatma Gandhi, the champion of nonviolent resistance and the father of nation of India writes about his childhood marriage and how he stole money from his home as a child and how he tried smoking and drinking. Tehmina Durrani, the then wife of the most famous Chief Minister of Pakistan's largest province of Punjab, wrote in her autobiography 'My Feudal Lord' how she cheated on her husband with whom she was married before getting married to Mustafa Khar the chief minister of Punjab. Protima Bedi, a prominent model in Bombay in the late sixties and early seventies, writes in her autobiography 'Timepass' about her lustful inclinations when she was in college. She also wrote about some of the known men of those days whom she had bedded with. She was known for running stark naked on the beach of Mumbai. In her autobiography 'Timepass' she says she had actually jogged bare naked on the beach of Goa and not in Mumbai. The newspapers reported it as a jogging on the beach of Mumbai just to create sensation, she said. This led to a great controversy in those days. The paper explores some of the incidences or confessions provided by some of the writers in their autobiographies. The paper also intends to understand the state of mind of some of these writers through the Freudian theory of id, ego and superego.

\section{ELEMENT OF FICTION IN THE AUTOBIOGRAPHIES}


When Qudratalullah Shahab wrote his autobiography 'Shahabnama' it was a magnum opus of his works and it was commercially a very successful book. Several editions of the book were published in the later years. When critical reviews started coming in the newspaper critics started questioning the accuracy of the events mentioned in the book. There were many incidences which looked like the stories of 'Arabian Nights' rather than looking like the events of a real life. At places he mentioned some incidences of ghosts and witches. He even mentioned the incidence of his written communication with some supernatural forces. He says when he was living at a rented house he used to hear the voice of a postman who used to knock at his door in the mid of a pitch black night and used to give him a letter. When he opened the letter in the morning he found that it was from a victim of a murder conspiracy. The victim was, may be from haven, asking the writer of the autobiography to reopen the murder case and get her justice by bringing the perpetrators to the gallows. Autobiographies also define the milieu or the society in which the author was brought up. Qudratullah Shahab also mentioned about the worst drought of Bengal which had killed thousands of people. He has also discussed the nonchalant behaviour of the British government of those days towards the victims who were dying by starvation. Most of the great autobiographies were written by great writers and the people of outstanding name. These people write their autobiographies thinking that the coming generation would like to know about their lives and general life in those days.

If you look at the history of autobiography or memoir you will find many autobiographies in every literature of the world. Western writers have also produced some of the greatest autobiographies. 'Unforgotten Years' is also one of the greatest autobiographies written by Pearsall Smiths's. 'Confessions' written by St. Augustine's is also a great autobiography. St. Augustine's for some time be4lieved in Manichaen religion which is system which believes in Christian, Gnostic, Pagan and other elements. This belief started in Persia. He later turned back to Christianity and he mentioned the religious right of passage ceremony in his autobiography.

Chateaubriand (1768-1848) a great French writer who wrote several books on romanticism also wrote his autobiography. The name of his autobiography is 'Memoires d'Outre - Tombe (1849-50). His autobiography gives the details of political upheaval in France in those days.

Aksakov Sergei Timofeyvichdrew, Russian author wrote the book Chronicles of a Russian Family (1856), Recollections (1856), Years of Childhood (1858). He mentioned the life of Russian villages. He also mentioned the rustic natural surroundings of those villages. His commentary about the life in Russia gives us an idea about the life in Russia of those days. While discussing the life there he discussed the cuisine and the style of dressing in the Russian villages in those days. He also gives us an idea about the culture and traditions and the way the marriages take place in those regions.

$\mathrm{T} \mathrm{N}$ Session one of the most known bureaucrats in the history of India and one of the best Chief Election Commissioners of the country, while explaining about an incidence of his life says that he was passing through the countryside in a convoy as election commissioner. His wife was also accompanying him and while passing they saw a beautiful well spun nest of birds. His wife asked him to stop the convoy and ask somebody to get her the nest. $\mathrm{T} \mathrm{N}$ Session did it and asked the driver to go and get the nest for his wife. Since the nest was on a high branch of the tree the driver looked around and called a shepherd boy to climb the tree and get the nest for them. The young illiterate shepherd was offered some money in return of this service. The boy looked at the convoy of cars and said no for getting the nest. The driver thought he is refusing it because the money offered to do it is less. He offered the double amount than before. The shepherd refused this time by saying, whatever you offer; I won't get it for you. T N Session who was listening to this conversation called the shepherd boy and asked him why he doesn't get the nest for them. The boy explained that this belongs to birds and maybe their little ones are inside the nest. If I pluck the nest and when the birds will come home in the evening, with food in their beaks and when they won't find their nest on its place they will be sad and hurt. T N Session was surprised to see the empathy of a young illiterate shepherd towards the birds. He says he although he cracked the highest public service commission exam in the country but that day a young illiterate shepherd taught him an important lesson in the life. This is an example of a candid confession.

Khushwant Singh (1915-2014) a well known diplomat and a journalist from India writes in his autobiography 'Truth, Love \& a Little Malice' how he went to England for higher studies through sea and how during the journey the ship halted at a port in Egypt and the first to rush in the ship from the dock was a bunch of female sex workers. Since the people on the ship were travelling for many days without their wives with them, many of them had great time with the call girls.

He also mentioned the domestic feuds between the former Prime Minister of India Indira Gandhi and her daughter in law Meneka Gandhi. He mentions how a great Prime Minister of India had domestic quarrels with her daughter in law just like a common Indian mother-in-law.

French novelist Marie-Henri Beyle better known as Stendhal (1783-1842) wrote his two well-known novels i.e. Le Rouge et le Noir(The Red and the Black1830) and La Chartreause de Parme(The Charterhouse of Parma1839). Both are notable for their psychological realism and political analysis. Souvenirs d' Egotisme (Memoirs of an Egoist 1892) is an autobiography written by Stendhal. Pascal checks with himself, before sitting to write an autobiography, what kind of a man he is and what positive aspects does his personality have. Once he receives the answers to these questions from his inner self he starts writing his autobiography. Since the novel is the author's recount of life in Paris and 
London from 1821 to 1830 , the method is used to retrace all the incidents of the ten years he spent there. It is needless to say that the book witnesses authors' remarks about himself a great deal about his way of life.

Great Russian novelist, Maxim Gorky, is well-known for his autobiographical trilogy i.e. My Childhood, In the World and My Universities (1915-23).My Childhood is his masterpiece which has been translated in many languages. An autobiography gives us the information about the conscience of the writer and also about the flow of ideas and thoughts in his mind. It also gives the real image of the inside human being to the people. This becomes important information or a revelation especially to the fans of a celebrity or a great political personality.

\section{DifFERENCE BETWEEN AUTOBIOGRAPHY AND BIOGRAPHY}

Biography and autobiography are quite different as it has already been discussed and defined that autobiography is a personal account of one's own life. On the contrary, biography is “a written account of a person's life, usually by another"(Oxford Reference Dictionary, p.144). An autobiography is a first-person account and sometimes the story can be highly personalised which may include photographs about the person's life events or newspaper articles. A. P. J. Abdul Kalam's Wings of Fire, for instance, best portrays the photos of the author, his family, friends, teachers and colleagues. It was Dryden who first used and defined the term Biography as "the history of particular men's lives" (quoted Prasad p.230). It is sufficient to draw a crystal clear line between a biography and an autobiography by adding Longfellow's statement that "Autobiography is a product of firsthand experience, Biography of second hand knowledge".

\section{CONFESSIONS, FACTS, FICTION AND HyPOTHESIS IN AUTOBIOGRAPHIES}

No human being can write or narrate all the incidences of his life without mentioning the bitter experiences he has had in his life. Every individual has some experiences in his life which, if given a chance, he would erase from the practical history of his life. In the same way no truthful autobiography can be complete without the mention of bitter experiences about the life of the writer. It is also true that here writer gets a chance of providing his apologia for the felonious behaviour at that time. This is the reason that many autobiographies have created controversies in the social and political world. There are several autobiographies which pulled the writers to court. Reham Khan, the erstwhile wife of Prime Minister of Pakistan, created a great controversy by mentioning a few scandalous things about her then husband Imran Khan. She decided to release the book exactly before the time of the national elections of the country. This is just an example. There are many autobiographies which created stir in the political and social world. Some of them have even been banned from publication or the writers have been asked to change certain portions of the narration. It is very difficult to churn out the truth from the incidences expressed in the autobiographies.

Mushfiq Khawaja one of the renowned satirists, and fiction writer of Urdu, while expressing his views about Qudratullah Shahab's Shahabnama, claims that the writer has exaggerated some of the incidences while narrated some of them inaccurately. He also claims that the writer has stretched the truth a little too long. Mushfiq Khawaja was one of the closest friends of the writer in his last days of life. He also claims that the writer has already discussed most of these incidences with him. He has even accused the writer for penning some of the fictitious incidences.

Protima Bedi in her autobiography 'Timepass' defends her decision of marrying Kabir Bedi at a young age against the will of her father. Although, she has also narrated that her marriage and rebellious behaviour might also be one of the reasons of the cardiac arrest of her father which resulted into his death, yet she did not rue her decisions. When she had her son she says her husband was in Hollywood shooting for a movie and when he returned back she told him without hesitating that this child is not his, but of a German friend of her. Her husband was shocked at this but then she defends herself by saying that she caught her husband several times cheating on her with other women. She has also mentioned the name of a Hindi movie actress with whom she had caught her husband several times.

Sigmund Freud describes the psychological aspect of a personality in three concepts id, ego and super-ego. Id is the set of instinctual desires. Like a child a man feels to have anything which attracts him. This may be desire of acquiring a lot of money by any means. Id forces man to acquire money by legal or illegal any mean. It may also be about the carnal desire like having carnal relations with a beautiful woman or a young girl. Id forces man to have relations with a beautiful woman legitimately or illegitimately. Id doesn't look at moral values or it doesn't look at what is socially or religiously acceptable or not. It even doesn't care about the statutory laws. The second thing is Super-ego which plays the role of a moral police and looks at every action through the prism of right or wrong. Every time one does something the super-ego checks if the act is socially acceptable or not. If the religion permits it or not. It is a kind of a moral police of an individuals' conscience. The third thing or the middle thing in between is the ego. Ego looks at things through the prism of realism. It asks and individual what is pragmatic? What is logically required? What is the need of the hour and what is practically right at the moment.

If you look at most of the autobiographies keenly you will find that it is a struggle between id and super-ego. Sometimes your ego loses a struggle against id and sometimes it loses against super-ego. No doubt generally it is ego which wins almost all the psychological dilemmas. Hence we can conclude here that most of the autobiographies are a struggle between id, ego and super-ego. 


\section{ACKNOWLEDGEMENTS}

The authors extend their appreciation to the Deanship of Scientific Research at King Khalid University for funding this work under Research grant award number RGP. 1/ 370 / 42.

\section{REFERENCES}

[1] Abrams, M. H. (2009). A Handbook of Literary Terms, Cenagage Learning India Private Limited. New York.

[2] Bedi, Protima. (2000). Timepass Penguin Books India.

[3] Durrani, Tehmina. (1991). My Feudal Lord Vanguard Books, Lahor, Pakistan.

[4] Gandhi M. K. (2009). An Autobiography the Story of My Experiments with Truth The Floating Press.

[5] Harvey, Paul. (1967). The Oxford Companion to English Literature, Oxford.

[6] Khan, Reham. (2018). Memoir Harper Collins India

[7] Leyden John and Erskine William. (1979). Memoirs of Zehir-Ed-Din Mohammed Baber. Sang e Meel Publications, Lahor, Pakistan.

[8] Pascal, Roy. (1960). Design and Truth in Autobiography, Routledge and Kegan Paul, London.

[9] Prasad, B. (1953). A Background to the Study of English Literature, Macmillan Pub. India.

[10] Shahab, Qudratullah. (2016). Shahabnaama Educational Publishing House, Delhi, India.

[11] Sharma R. (2004). Autobiographical Writings of Mahatma Gandhi, Deep \& Deep Publication. Delhi, India.

[12] The Oxford English Reference Dictionary. (1995). Oxford New York, (OUP). Oxford, U.K.

Mohammed Osman did his PhD in Literature from Dr B A Marathwada University of India in Literature. He did his B A from Mumbai University and M A from Dr B A Marathwada University of India. He has been teaching English at King Khaled University for last seven years. He has been involved in teaching Grammar, Writing, and Reading. He is in charge King Khalid University department of Language and Translation Examination committee. He has interest in research in the field of linguistic, autobiographies and short stories in literature.

Nisar Ahmad Koka, being highly motivated in carrying out teaching and research in the field of linguistics, did his M.A. and Ph.D. in Theoretical and Sociolinguistics Linguistics from Aligarh Muslim University Aligarh, India in 1998 and 2002 respecti vely. He has been engaged in teaching linguistics /applied linguistics and English as a Foreign Language (EFL) in different universities/institutions for last 18 years or so. Dr. Koka has published more than half a dozen of research articles in different national and international journals, and has also presented several papers in various conferences/seminars covering various themes and topics concerning linguistics and language teaching. He has also co-authored 3 books on 'Testing and Evaluation' in Indian Languages while working as junior resource person on the projects of Multipurpose Indian Language Evaluation System (MILES) and National Testing Service (NTS) India. Dr. Koka is currently engaged as an assistant professor at the Department of English, Faculty of Languages and Translation, King Khalid University Abha, KSA teaching English as Foreign Language (EFL).

Mohammed Nurul Islam (Ph.D) is an assistant professor in the Department of English, Faculty of Languages and Translations, King Khalid University, Kingdom of Saudi Arabia Since 2009. His areas of interest include ELT, ESP and World English. 